Prepared in cooperation with the International Joint Commission and Environment Canada

\title{
Hydrographic Surveys of Four Narrows within the Namakan Reservoir System, Voyageurs National Park, Minnesota, 2011
}

Data Series 792

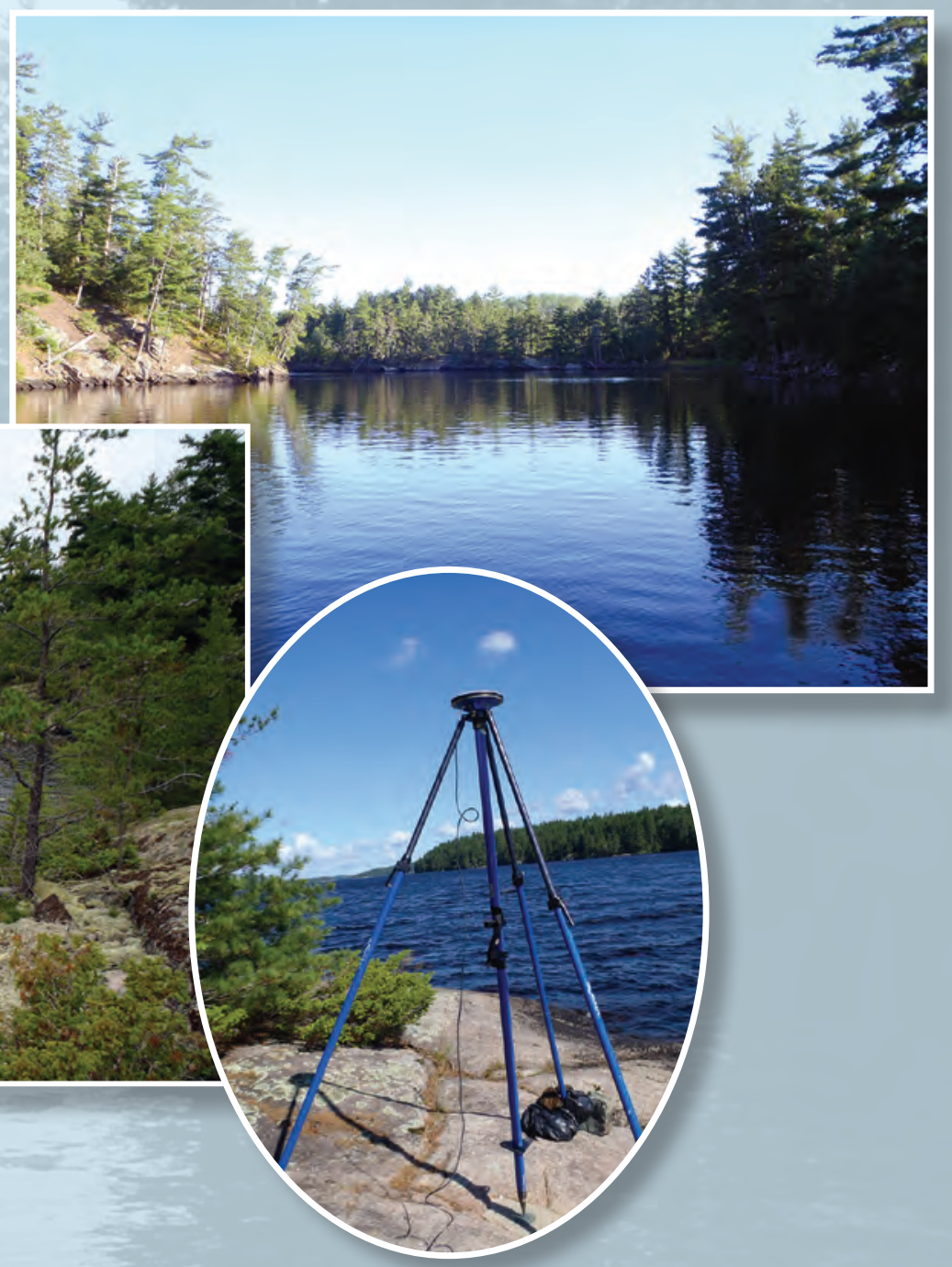

U.S. Department of the Interior

U.S. Geological Survey 
Cover photographs. Left and right top photographs are King Williams Narrows. Right lower oval photograph is a dual frequency Global Positioning System (GPS) unit collecting static-mode data at the Little Vermilion Narrows benchmark. Photographs by Brenda Densmore, U.S. Geological Survey, Nebraska Water Science Center, on August 9, 2011. 


\section{Hydrographic Surveys of Four Narrows within the Namakan Reservoir System, Voyageurs National Park, Minnesota, 2011}

By Brenda K. Densmore, Kellan R. Strauch, and Jeffrey R. Ziegeweid

Prepared in cooperation with the International Joint Commission and Environment Canada

Data Series 792 


\title{
U.S. Department of the Interior SALLY JEWELL, Secretary
}

\section{U.S. Geological Survey Suzette M. Kimball, Acting Director}

\author{
U.S. Geological Survey, Reston, Virginia: 2013
}

For more information on the USGS - the Federal source for science about the Earth, its natural and living resources, natural hazards, and the environment, visit http://www.usgs.gov or call 1-888-ASK-USGS.

For an overview of USGS information products, including maps, imagery, and publications, visit http://www.usgs.gov/pubprod

To order this and other USGS information products, visit http://store.usgs.gov

Any use of trade, firm, or product names is for descriptive purposes only and does not imply endorsement by the U.S. Government.

Although this information product, for the most part, is in the public domain, it also may contain copyrighted materials as noted in the text. Permission to reproduce copyrighted items must be secured from the copyright owner.

Suggested citation:

Densmore, B.K., Strauch, K.R., and Ziegeweid, J.R., 2013, Hydrographic surveys of four narrows within the Namakan reservoir system, Voyageurs National Park, Minnesota, 2011: U.S. Geological Survey Data Series 792, 12 p., http://pubs.usgs.gov/ds/792/. 


\section{Contents}

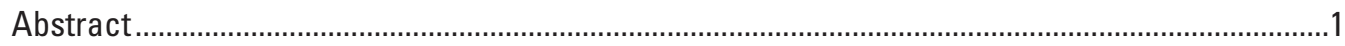

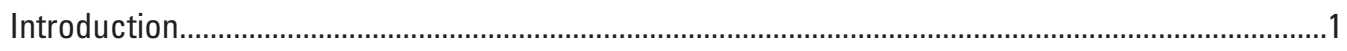

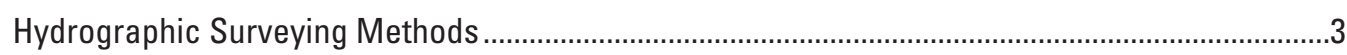

Hydrographic Surveys of Four Narrows within the Namakan Reservoir System.............................

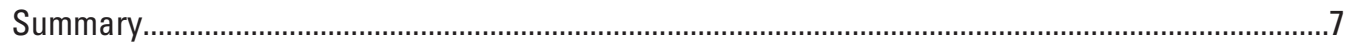

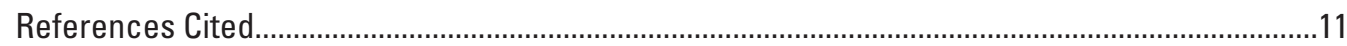

\section{Figures}

1. Map showing surveyed narrows areas of the Namakan reservoir system .......................2

2. Map showing bathymetry surveyed August 10-11, 2011, at Harrison Narrows, Sand Point Lake, Minnesota-Ontario

3. Map showing bathymetry surveyed August 13,2011 , at Namakan Narrows, Sand Point Lake, Minnesota-Ontario

4. Map showing bathymetry surveyed August 14,2011 , at Little Vermilion Narrows of Little Vermilion Lake, and August 15, 2011, at King Williams Narrows of Crane Lake, Minnesota-Ontario

\section{Tables}

1. Location and accuracy of U.S. Geological Survey established benchmarks ...................5

2. Hydrographic survey date and summary of surveyed elevations and survey area, for four selected narrows, Namakan reservoir system, Minnesota-Ontario, 2011

3. Summary of vertical uncertainty of hydrographic surveys of four selected narrows, Namakan reservoir system, Minnesota-Ontario, 2011. 


\section{Conversion Factors}

SI to Inch/Pound

\begin{tabular}{lcl}
\hline \multicolumn{1}{c}{ Multiply } & By & \multicolumn{1}{c}{ To obtain } \\
\hline millimeter $(\mathrm{mm})$ & Length & inch (in) \\
meter $(\mathrm{m})$ & 0.03937 & foot $(\mathrm{ft})$ \\
meter $(\mathrm{m})$ & 3.281 & yard (yd) \\
\hline & 1.094 & \\
\hline square kilometer $\left(\mathrm{km}^{2}\right)$ & Area & acre \\
square kilometer $\left(\mathrm{km}^{2}\right)$ & 247.1 & square mile $\left(\mathrm{mi}^{2}\right)$ \\
\hline & 0.3861 & acre \\
\hline meters per second $(\mathrm{m} / \mathrm{s})$ & Velocity & \\
\hline & 0.0002471 & cycle $/$ second \\
\hline kilohertz $(\mathrm{kHz})$ & Frequency & \\
\hline
\end{tabular}

Vertical coordinate information is referenced to the North American Vertical Datum of 1988 (NAVD 88).

Horizontal coordinate information is referenced to the North American Datum of 1983 (NAD 83) Continuously Operating Reference Stations network, 1996 adjustment (CORS96). 


\title{
Hydrographic Surveys of Four Narrows within the Namakan Reservoir System, Voyageurs National Park, Minnesota, 2011
}

\author{
By Brenda K. Densmore, Kellan R. Strauch, and Jeffrey R. Ziegeweid
}

\section{Abstract}

The U.S. Geological Survey performed multibeam echosounder hydrographic surveys of four narrows in the Namakan reservoir system in August 2011, in cooperation with the International Joint Commission and Environment Canada. The data-collection effort was completed to provide updated and detailed hydrographic data to Environment Canada for inclusion in a Hydrologic Engineering Centers River Analysis System hydraulic model. The Namakan reservoir system is composed of Namakan, Kabetogama, Sand Point, Crane, and Little Vermilion Lakes. Water elevations in the Namakan reservoir system are regulated according to rule curves, or guidelines for water-level management based on the time of year, established by the International Joint Commission. Water levels are monitored by established gages on Crane Lake and the outlet of Namakan Lake at Kettle Falls, but water elevations throughout the system may deviate from these measured values by as much as 0.3 meters, according to lake managers and residents. Deviations from expected water elevations may be caused by between-lake constrictions (narrows). According to the 2000 Rule Curve Assessment Workgroup, hydrologic models of the reservoir system are needed to better understand the system and to evaluate the recent changes made to rule curves in 2000.

Hydrographic surveys were performed using a RESON SeaBat ${ }^{\mathrm{TM}} 7125$ multibeam echosounder system. Surveys were completed at Namakan Narrows, Harrison Narrows, King Williams Narrows, and Little Vermilion Narrows. Hydrographic survey data were processed using Caris HIPS ${ }^{\mathrm{TM}}$ and SIPS ${ }^{\mathrm{TM}}$ software that interpolated a combined uncertainty and bathymetric estimator (CUBE) surface. Quality of the survey results was evaluated in relation to standards set by the International Hydrographic Organization (IHO) for describing the uncertainty of hydrographic surveys. More than 90 percent of the surveyed areas at the four narrows have resulting bed elevations that meet the IHO "Special Order" quality. Survey datasets published in this report are formatted as text files of $\mathrm{x}-\mathrm{y}-\mathrm{z}$ coordinates and as CARIS Spatial Archive ${ }^{\mathrm{TM}}\left(\mathrm{CSAR}^{\mathrm{TM}}\right)$ files with corresponding metadata.

\section{Introduction}

The Namakan reservoir system is composed of Namakan, Kabetogama (not shown), Sand Point, Crane, and Little Vermilion Lakes (fig. 1). The reservoir system is located in northern Minnesota, within the boundaries of Voyageurs National Park, Superior National Forest, and partially within the Boundary Waters Canoe Area Wilderness. It is upstream from Rainy Lake (not shown) and is one of the Canada-United States boundary waters (fig. 1). As a boundary water, the International Joint Commission (IJC) regulates the system with assistance from a board created by the commission, the International Rainy Lake Board of Control (IRLBC) (International Rainy Lake Board of Control, 1999). The IJC used input from the IRLBC to develop rule curves that specify upper and lower allowable water levels for Rainy Lake and the Namakan reservoir system. The rule curves account for natural seasonal fluctuations in water level while balancing the requirements for several legally recognized water uses within the Namakan reservoir-system basin (Kallemeyn and others, 2003).

Water levels in the Namakan reservoir system and in Rainy Lake (not shown) are controlled by three dams. The dam controlling waterflow out of Rainy Lake is located at Fort Frances, Ontario, and International Falls, Minnesota, and is called Rainy Lake Dam (not shown). Two dams control the flow of water from Namakan Lake into Rainy Lake (not shown), one at Kettle Falls and one at Squirrel Falls, Ontario. These three dams are the source of hydroelectric power for the paper pulp industrial facilities of the Boise Cascade Corporation and the Abitibi Consolidated, Inc. Water levels in the system are monitored by gages located at Crane Lake, Kettle Falls Dam, and Rainy Lake Dam (not shown).

Rule curves designed to maintain IJC-mandated water levels on Rainy Lake and the Namakan reservoir system went through several modifications until the 1970 Order (Kallemeyn and others, 2009) implemented new rule curves. The 1970 rule curves called for water-level control practices that deviated from the natural flow conditions in two ways: winter drawdown delayed spring filling and peak water levels by 1 month; and water levels were held high throughout the 


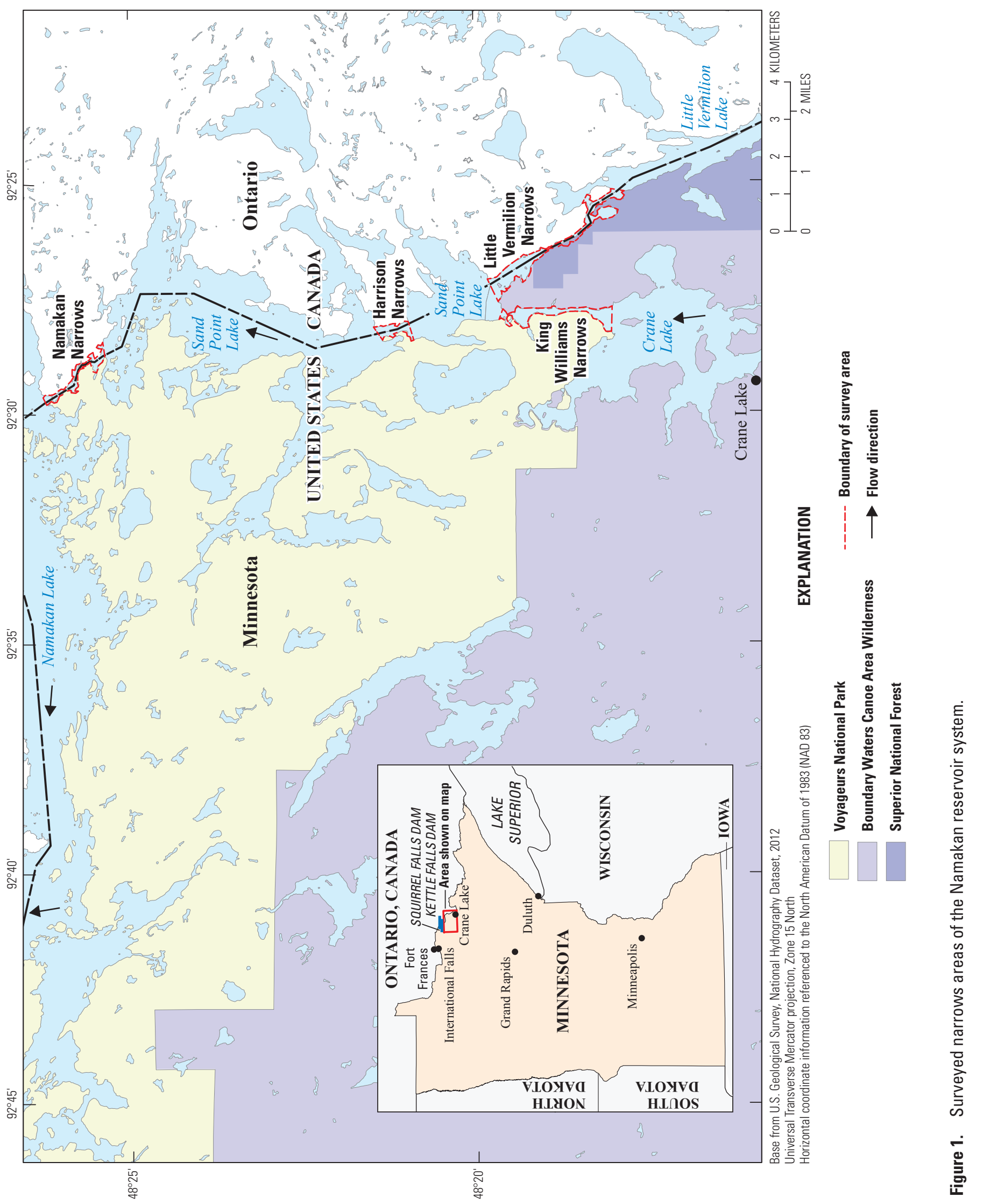


summer and early autumn, and did not gradually decline through the season (Kitchell and Koshinsky, 1996). Implementation of the 1970 rule curves led to large water-level fluctuations, ultimately resulting in low water levels that concerned resort owners. In addition, the unnatural water-level management limited possibilities for restoration of the natural lake system in Voyageurs National Park, causing water levels mandated by the 1970 rule curves to conflict with the National Park Service goal of restoring natural processes to Voyageurs National Park. Furthermore, when implementing the 1970 rule curve-mandated water levels, resource managers documented continual decline in fish populations and attributed it, in part, to diminished spawning success because of water-level management practices. Therefore, despite some concerns about possibly increased flood risks, impediments to recreational boating, and other economic issues (Kitchell and Koshinsky, 1996), the rule curves for Rainy Lake and the Namakan reservoir system were revised by the 2000 Order (International Joint Commission, 2001).

The IJC 2000 Order consolidated previous orders and their supplementary orders, set forth new rule curves, and included the following statement on review: "This Order shall be subject to review 15 years following adoption of the Commission's Supplementary Order of 5 January 2000, or as otherwise determined by the Commission. The review shall, at minimum, consider monitoring information collected by natural resource management agencies and others during the interim that may indicate the effect of the changes contained in the Supplementary Order of January 5, 2000" (International Joint Commission, 2001). In 2007, a 2000 Rule Curve Assessment Workgroup was established to (1) determine what monitoring data would be available from resource management agencies and others, and (2) determine data that would be needed to assess the 2000 rule curves by 2015 . The work group identified that one core study need was the development of reservoir hydrologic models (Kallemeyn and others, 2009). The need for a reservoir hydrologic model became clear when lake managers and residents noticed that water levels monitored at Crane Lake and Kettle Falls Dam did not accurately represent water levels throughout the system (Revell, 2010), which can deviate from gage values by as much as 0.3 meters (m). The complexity of the Namakan reservoir system and the effects of the constricting connections between the water bodies, called "narrows," could be a factor in the variation of water levels throughout the system. These narrows may constrict water movement and create transitory changes in water-surface elevations and travel time through the system. To accurately represent these narrows in a hydrologic model, detailed, up-to-date hydrographic survey data were needed.

The U.S. Geological Survey (USGS) Nebraska Water Science Center (NEWSC) and the Minnesota Water Science Center (MNWSC) performed multibeam echosounder hydrographic surveys of four selected narrows in the Namakan reservoir system in August 2011, in cooperation with the International Joint Commission and Environment Canada. This report provides updated and detailed hydrographic data to Environment Canada suitable for inclusion in a Hydrologic Engineering Center River Analysis System (HEC-RAS) hydraulic model.

In addition to the hydrographic survey data presented in this report, the USGS MNWSC collected water-velocity and water-level data in 2011 and 2012 that also will aid Environment Canada in the development of a HEC-RAS hydraulic model of the Namakan reservoir system. Water-velocity data were collected as part of discharge measurements completed according to Rantz and others (1982), and resulting measurement data can be located online at http://waterdata.usgs.gov/ mn/nwis/measurements (U.S. Geological Survey, 2012a). Water-level data were collected continuously in four pools of the Namakan reservoir system using submersible pressure transducers. Transducers were located at four stations: (1) Little Vermilion Lake upstream from Little Vermilion Narrows, (2) Sand Point Lake upstream from Harrison Narrows, (3) Sand Point Lake downstream from Harrison Narrows, and (4) Namakan Lake downstream from Namakan Narrows. Transducer water levels are indexed to vertical datum using reference marks set at each station; reference elevation for these marks was established during the bathymetric surveys discussed in this report. Water-level data for the four stations can be found in the 2012 MNWSC Annual Data Report (U.S. Geological Survey, 2012b).

\section{Hydrographic Surveying Methods}

Hydrographic surveys were performed using a highresolution multibeam echosounder (MBES) mapping system. The system is made up of several components including the MBES, the inertial measurement unit (IMU) and navigation system, and a data-collection/navigation computer. The

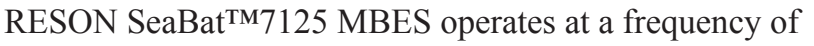
400 kilohertz $(\mathrm{kHz})$ and was run in the equi-distance mode during the surveys. The equi-distance mode collects 512 equally spaced depth readings each time the sonar projector transmits one sound wave, which has been formed into 0.5 degree $\left(^{\circ}\right)$ beams. In this instrument setting, the beams cover a $128^{\circ}$ cross-track swath that is focused in a $1^{\circ}$ alongtrack area (RESON, Inc., 2006). The maximum depth range that this sonar is rated to survey is $200 \mathrm{~m}$. Further details of the RESON SeaBat ${ }^{\mathrm{TM}} 7125$ and the other MBES mapping-system components can be found in Densmore and others (2013).

Field-collection procedures used during the surveys at the four Namakan reservoir narrows were similar to those described in Densmore and others (2013). Global positioning system (GPS) benchmarks were established by chiseling an " $\mathrm{X}$ " in the rock bank of the survey area at each narrows. One benchmark was created at each of the four narrows. Before hydrographic surveying, static-mode dual frequency GPS data were collected on each benchmark (using an Ashtech Geodetic II GPS antenna and an Ashtech Z-Xtreme receiver) and processed through the National Geodetic Survey (NGS) Online 
Hydrographic Surveys of Four Narrows within the Namakan Reservoir System, Voyageurs National Park, Minnesota, 2011

Positioning Users Service (OPUS) (National Geodetic Survey, 2012) to establish survey-grade coordinates: horizontal coordinates as North American Datum of 1983 [NAD 83; with NGS Continuously Operating Reference Stations network, 1996 adjustment (CORS96)] latitude and longitude, and as Universal Transverse Mercator (UTM) Zone 15 North northing and easting positions reported to the millimeter; and vertical coordinates as Geodetic Reference System 1980 (GRS80) ellipsoid heights, and as North American Vertical Datum 1988 (NAVD 88) orthometric heights, calculated using Geoid09 (National Geodetic Survey, 2011) and reported to the millimeter. Permanent benchmarks and secondary check points were not set because the survey areas were within the national park boundary. Typical real-time kinematic (RTK) GPS surveying includes at least one known benchmark in addition to the benchmark occupied by the base station. This second benchmark is used to verify the setup of the base station and rover units before surveying each day. For this study, however, a second benchmark was not established or used to check during the surveys to limit the effect on the national park. Quality control of the surveys included setting up the base station to occupy previously established benchmarks, logging the basestation position in static mode throughout the daily survey, and sending the static data collected over the benchmarks to OPUS daily to verify that the base station had been set up and operating correctly.

During the survey, data being collected were monitored and evaluated by the sonar or echosounder operator to ensure quality as described in Densmore and others (2013). Each day, a manual water-depth measurement was compared to the depth measured by the nadir beam to ensure the accuracy of the sonar. Speed-of-sound profiles were collected several times throughout the survey area during data collection, because there was a possibility of velocity stratification in the water column. Speed-of-sound data were applied during postprocessing to accurately correct the depth measurements. Patchtest data were collected and evaluated, as described in Densmore and others (2013), to determine the precise mounting angles of the MBES projector and receiver units in relation to the IMU. The sonar head intentionally was tilted -20 degrees from vertical along the cross-track direction so that the shallow sections of the survey areas and the vertical rock and bank structures could be surveyed more efficiently. Vertical and horizontal offset values, or $\mathrm{x}-\mathrm{y}-\mathrm{z}$ distance measurements, between each mapping-system component were established using a total-station surveying instrument. The offset values and patch-test values were applied to all the data either during data collection or during processing.

Processing of the MBES data was completed with the CARIS HIPS ${ }^{\mathrm{TM}}$ program (CARIS, 2012). The first step in processing MBES data using the HIPS ${ }^{\mathrm{TM}}$ program was to create a vessel file containing offset, calibration, and dataquality information. Using the vessel file, the survey project was created and the raw data files, which had been collected using HYPACK $® / H Y S W E E P ®(. H S X)$ (HYPACK, Inc. 2007), were opened in the HIPS ${ }^{\mathrm{TM}}$ project. The raw data were corrected by applying the water column speed-of-sound vertical profile data and, when needed, revised tide or watersurface values. Filters also were applied to remove some data points that did not agree to within $0.01 \mathrm{~m}$ of nearby data points, as well as data points that were flagged as having low quality, either because they were collected at low signal strength or because they were not collinear in elevation/depth, or both, as well as data points from the extreme outside beams of the swath $\left(9^{\circ}\right.$ of outer beams removed from starboard and $4^{\circ}$ of the outer beam removed from port, leaving a $75^{\circ}$ swath on starboard and a $40^{\circ}$ swath on port). Data from the outside beams were removed because they typically had low signalto-noise ratios; when data coverage is sufficient, removal of these data will not affect the completeness of the survey. After these corrections and deletions were made, a total propagated uncertainty (TPU) estimate was made for each sounding in the dataset. A TPU estimate has two components: a horizontal error estimate and a depth error estimate (CARIS, 2011). A TPU estimate was calculated based on error estimates found in the vessel file, which include error estimates for each sensor (GPS, IMU, MBES, and others) as well as error estimates for parameter measurements (speed of sound) and offsets (mounting angles). TPU estimates ultimately are used to produce a combined uncertainty and bathymetric estimator (CUBE) surface. The CUBE surface grid was interpolated by weighting soundings based on TPU value and distance from a node (or cell center) (CARIS, 2011). The CUBE surface calculations result in multiple depth estimates (hypotheses), but the selected depth estimate was constrained using disambiguation parameters set by the surveyor. The surveyor then reviewed the CUBE surface and, in areas where an incorrect depth estimate might have been chosen, the surveyor manually edited the data points to ensure the selection of the correct depth estimate. A CUBE surface interpolation eliminates the need for the surveyor to manually delete every incorrect data point, because most erroneous points were not selected to contribute to the final depth estimate, but manual editing still can be completed where needed. In addition, the CUBE surface processing method also reduces bias introduced by manual editing.

After the CUBE surface was evaluated and finalized by the surveyor, the dataset, as represented by points at grid cell centroids, was exported as the final $x-y-z$ dataset. The CUBE surface created for each Namakan narrows survey area and derived products was represented as a grid of $0.5-\mathrm{m}$ by $0.5-\mathrm{m}$ cells. In addition to the $x-y-z$ text files of the final datasets, the CARIS Spatial Archive ${ }^{\mathrm{TM}}\left(\mathrm{CSAR}^{\mathrm{TM}}\right)$ files of the final datasets are published with this report for easy two-dimensional (2-D) and three-dimensional (3-D) viewing using software called CARIS Easy View ${ }^{\mathrm{TM}} 4.0$ (CARIS, 2013) or other software capable of opening this type of file (.csar).

Horizontal and vertical accuracy of the survey is dependent on the accuracy of the GPS surveyed position, the sonar angle measurement, the boat motion data, and the sonar distance measurement. The GPS survey accuracy partly is dependent on the accuracy of USGS-established benchmarks (chiseled "X"). One way OPUS evaluates the quality of the 
coordinates determined from processing a static dataset is by calculating peak-to-peak errors (National Geodetic Survey, 2012). Peak-to-peak errors ranged from $0.002-0.088 \mathrm{~m}$ in the horizontal coordinates and from $0.012-0.066 \mathrm{~m}$ in the vertical height coordinates for USGS-established benchmarks at the Namakan narrows (table 1). GPS accuracy is not only determined by the base station's positional accuracy, but also by the accuracy of the rover unit. The rover unit used during MBES surveying was an Applanix POS MVTM WaveMaster, which utilized the base station's positional correction information along with data from two GPS antennas mounted on the survey boat and an IMU. The positional accuracy of the rover unit is assumed to be plus or minus $0.02-0.04 \mathrm{~m}$, for a fixed quality solution, as reported in manufacturer's specifications for the POS MV TM WaveMaster (Applanix Corporation, 2006). In addition, the specifications for the POS MVTM WaveMaster report that the unit estimates roll and pitch of the boat with an accuracy of plus or minus 0.02 degrees utilizing RTK corrections for position. Resolution of depth estimation (or sonar travel distance), as described by RESON, Inc. (2006) for the SeaBat ${ }^{\mathrm{TM}} 7125$ multibeam echosounder, is adequate to yield an uncertainty for water depth of $0.005 \mathrm{~m}$.

The actual accuracy of hydrographic surveys typically cannot be determined; however, the International Hydrographic Organization (IHO) has set standards for describing the uncertainty in a hydrographic survey (International Hydrographic Organization, 2008). The quality of a hydrographic survey is described by the IHO as orders, with "special order" being the highest quality followed by $1 \mathrm{a}, 1 \mathrm{~b}$, and 2 or secondorder designations. The CUBE surface of each surveyed narrows was created from only those data points that had a TPU value that meets the IHO "special order" standard. The final CUBE surfaces also were evaluated in relation to IHO standards as suggested by Dartnell and others (2012). Dartnell and others (2012) suggested that total vertical uncertainty (TVU) can be estimated as

$$
T V U_{(x, y)}=1.96 \sigma_{(x, y)}
$$

where

$$
\begin{gathered}
\sigma_{(x, y)} \text { is the standard deviation of the soundings in } \\
\text { the cell located at coordinates } x \text { and } y .
\end{gathered}
$$

The standard deviation (called Std_Dev) is calculated as part of the CARIS CUBE surface interpolation and is the standard deviation of the data points contributing to the chosen depth estimate. The grid of Std_Dev values for each of the four survey areas were exported from CARIS and compared to depth-standardized maximum allowable TVU for each IHO order (International Hydrographic Organization, 2008) using ArcMap software (ESRI, 2012).

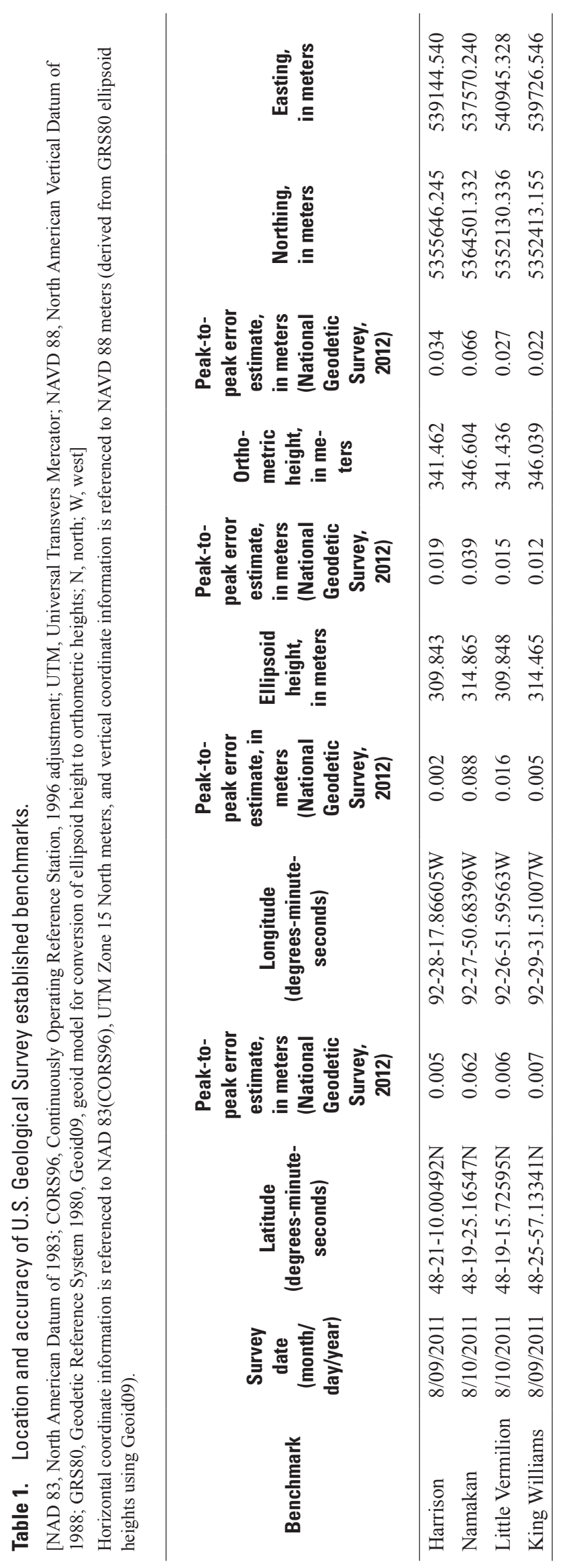




\section{Hydrographic Surveys of Four Narrows within the Namakan Reservoir System}

Hydrographic surveys of four narrows within the Namakan reservoir system were performed August 8-15, 2011 (tables 1 and 2). The surveys of the four narrows covered a total of 1.61 square kilometers $\left(\mathrm{km}^{2}\right)$ with bed elevations ranging from 316.5 to $340.7 \mathrm{~m}$ above NAVD 88 (table 2). The reduced, final dataset contains $6,441,421$ survey points.

Vertical sound-velocity profiles collected at each narrows indicated stratification was present, so the velocity-profile data were used to correct the soundings in postprocessing. The speed-of-sound at Harrison Narrows ranged from 1,440 to 1,490 meters per second (m/s); at Namakan Narrows ranged from 1,447 to $1,494 \mathrm{~m} / \mathrm{s}$; at Little Vermilion Narrows ranged from 1,450 to $1,498 \mathrm{~m} / \mathrm{s}$; and at King Williams Narrows ranged from 1,488 to $1,498 \mathrm{~m} / \mathrm{s}$.

Patch tests completed during the survey of the four Namakan narrows determined pitch of the sonar head in relation to the orientation of the IMU to be $-3.00^{\circ}$, roll to be $-19.6^{\circ}$, and yaw to be $3.50^{\circ}$. Patch tests determined that there was no timing offset present between the positioning data and the sonar data, so latency was 0 seconds. The final datasets show offset errors even though patch-test correction values have been applied. These offset errors are seen typically as slight elevation offsets between overlapping passes or sideby-side passes. These errors are most pronounced at Little Vermilion Narrows because it was shallow and limited the overlap between swaths.

TVU values for depth estimates were compared to depth-standardized maximum allowable TVU for each IHO order of quality (International Hydrographic Organization, 2008), and the percentage of grid cells that met each order was determined. The results show that all data collected at the four narrows meet the criteria for an IHO order 1a survey, and more than 90 percent of the data meet the requirements for an IHO special order survey (table 3 ). In addition, the maximum CUBE uncertainty estimate, which is the final vertical uncertainty associated with each cell's depth estimate, based on the uncertainty of the soundings that contributed to that particular estimate, was not greater than $0.33 \mathrm{~m}$ for any cell in the four surveyed areas.

Table 2. Hydrographic survey date and summary of surveyed elevations and survey area, for four selected narrows, Namakan reservoir system, Minnesota-Ontario, 2011.

[NAVD 88, North American Vertical Datum of 1988; GRS80, Geodetic Reference System 1980; Geoid09, geoid model for conversion of ellipsoid height to orthometric heights; $\mathrm{km}^{2}$, square kilometer]

Vertical coordinate information is referenced to NAVD 88 (derived from GRS80 ellipsoid heights using Geoid09).

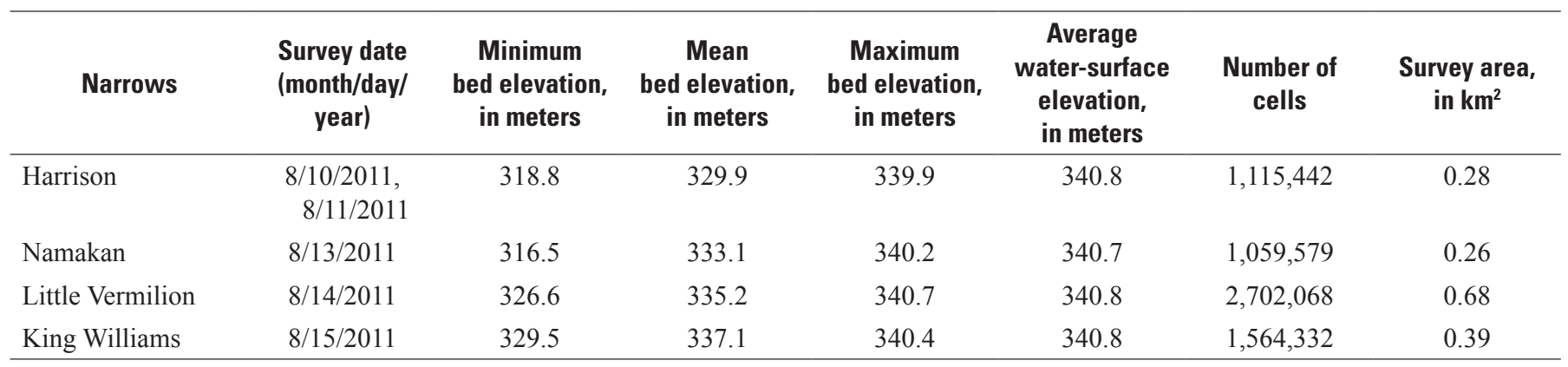

Table 3. Summary of vertical uncertainty of hydrographic surveys of four selected narrows, Namakan reservoir system, MinnesotaOntario, 2011.

[IHO, International Hydrographic Organization; CUBE, combined uncertainty and bathymetric estimator]

\begin{tabular}{|c|c|c|c|c|c|c|}
\hline Narrows & $\begin{array}{c}\text { Mean cell } \\
\text { standard deviation, } \\
\text { in meters }\end{array}$ & $\begin{array}{c}\text { Maximum cell } \\
\text { standard deviation, } \\
\text { in meters }\end{array}$ & $\begin{array}{l}\text { Grid cells meeting } \\
\text { or exceeding IHO } \\
\text { special order } \\
\text { survey quality, } \\
\text { in percent }\end{array}$ & $\begin{array}{l}\text { Grid cells meeting } \\
\text { or exceeding } \\
\text { IHO first order 1a } \\
\text { survey quality, } \\
\text { in percent }\end{array}$ & $\begin{array}{l}\text { Mean CUBE } \\
\text { uncertainty, } \\
\text { in meters }\end{array}$ & $\begin{array}{l}\text { Maximum CUBE } \\
\text { Uncertainty, } \\
\text { in meters }\end{array}$ \\
\hline Harrison & 0.06 & 0.49 & 96.7 & 100 & 0.14 & 0.33 \\
\hline Namakan & 0.06 & 0.41 & 92.6 & 100 & 0.22 & 0.30 \\
\hline King Williams & 0.03 & 0.20 & 100 & 100 & 0.10 & 0.18 \\
\hline
\end{tabular}

${ }^{1}$ As described by International Hydrographic Organization, 2008. 
The final survey dataset at each narrows is shown in figures 2-4. The complete channel of each narrows was surveyed in most cases. The datasets are published as part of this report in two formats: text files of comma-delimited values (.csv) and CARIS CSAR ${ }^{\mathrm{TM}}$ files (.csar). Federal Geographic Data Committee-compliant metadata associated with each dataset also are included as part of this report.

\section{Summary}

The Namakan reservoir system is composed of Namakan, Kabetogama, Sand Point, Crane, and Little Vermilion Lakes in northern Minnesota, within the boundaries of Voyageurs National Park, Superior National Forest, and partially within the Boundary Waters Canoe Area Wilderness. Contractions, or narrows, in the waterways connecting the system lakes may constrict water movement and create transitory changes in water-surface elevations and travel time through the system. The need for a hydrologic model of the reservoir system became clear when water levels monitored at Crane Lake and Kettle Falls gages did not accurately represent water levels throughout the system.
Hydrographic surveys of four selected Namakan reservoir system narrows were completed by the U.S. Geological Survey in August 2011, in cooperation with the International Joint Commission and Environment Canada, with the aim to produce high-quality, detailed bathymetric maps of Namakan, Harrison, King Williams, and Little Vermilion Narrows. The data published with this report provide updated and detailed hydrographic data to Environment Canada suitable for inclusion in a Hydrologic Engineering Centers River Analysis System hydraulic model.

The surveys were performed using a RESON SeaBat ${ }^{\text {TM}} 7125$ multibeam echosounder system and processed using CARIS HIPS ${ }^{\mathrm{TM}}$ and SIPS ${ }^{\mathrm{TM}}$ software by creating a combined uncertainty and bathymetric estimator (CUBE) surface. The surveys covered a total area of 1.61 square kilometers, the bed elevations ranged from 316.5 to $340.7 \mathrm{~m}$ above NAVD 88 , and the final, reduced datasets contain $6,441,421$ points. More than 90 percent of each dataset consists of bed elevations having vertical uncertainties that meet the "special order" survey standards described by the International Hydrographic Organization (IHO). Survey results are published along with this report in two formats, which include $\mathrm{x}-\mathrm{y}-\mathrm{z}$ text files and CARIS Spatial Archive ${ }^{\mathrm{TM}}\left(\mathrm{CSAR}^{\mathrm{TM}}\right)$ files, each with corresponding metadata. 


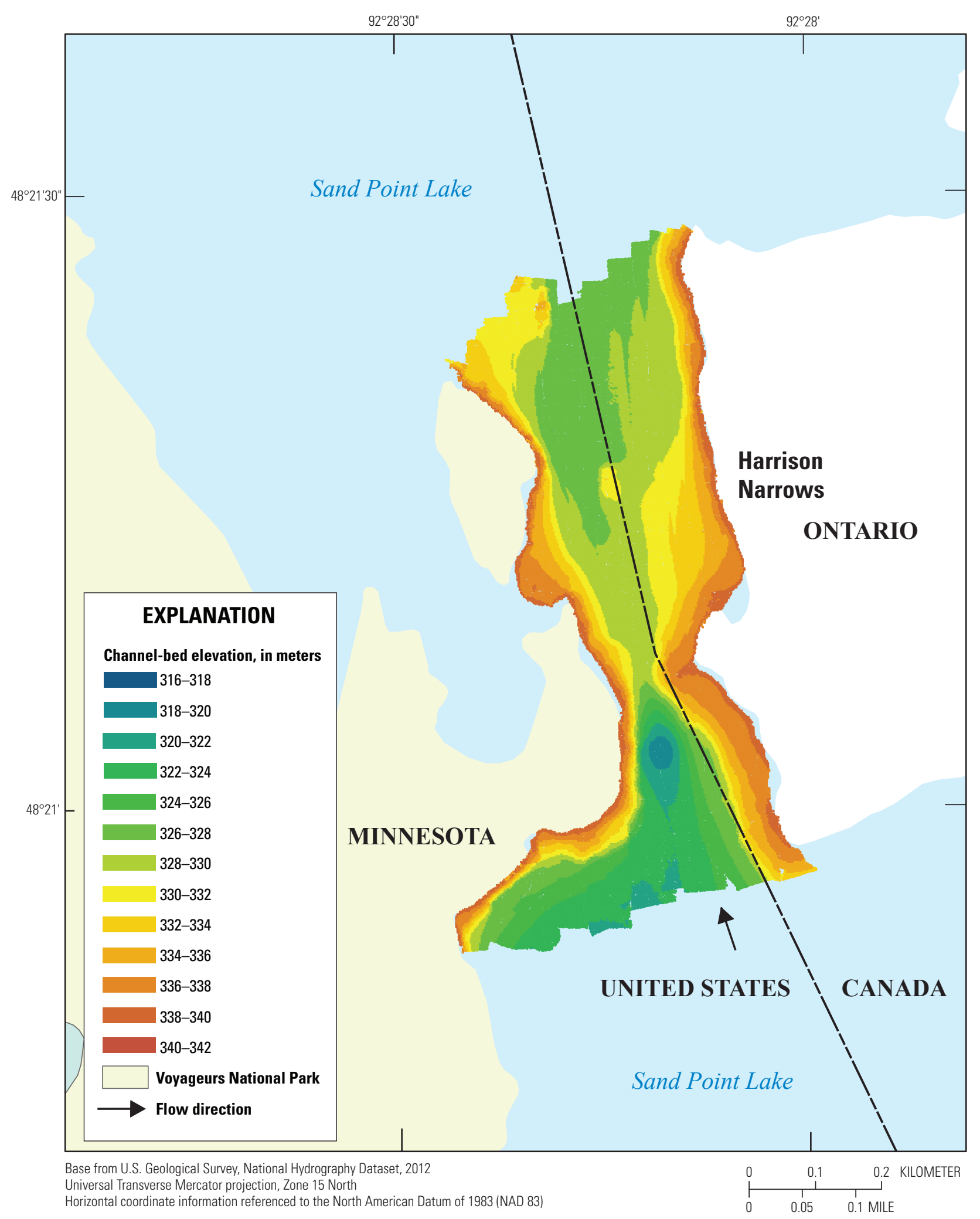

Figure 2. Bathymetry surveyed August 10-11, 2011, at Harrison Narrows, Sand Point Lake, Minnesota-Ontario. 


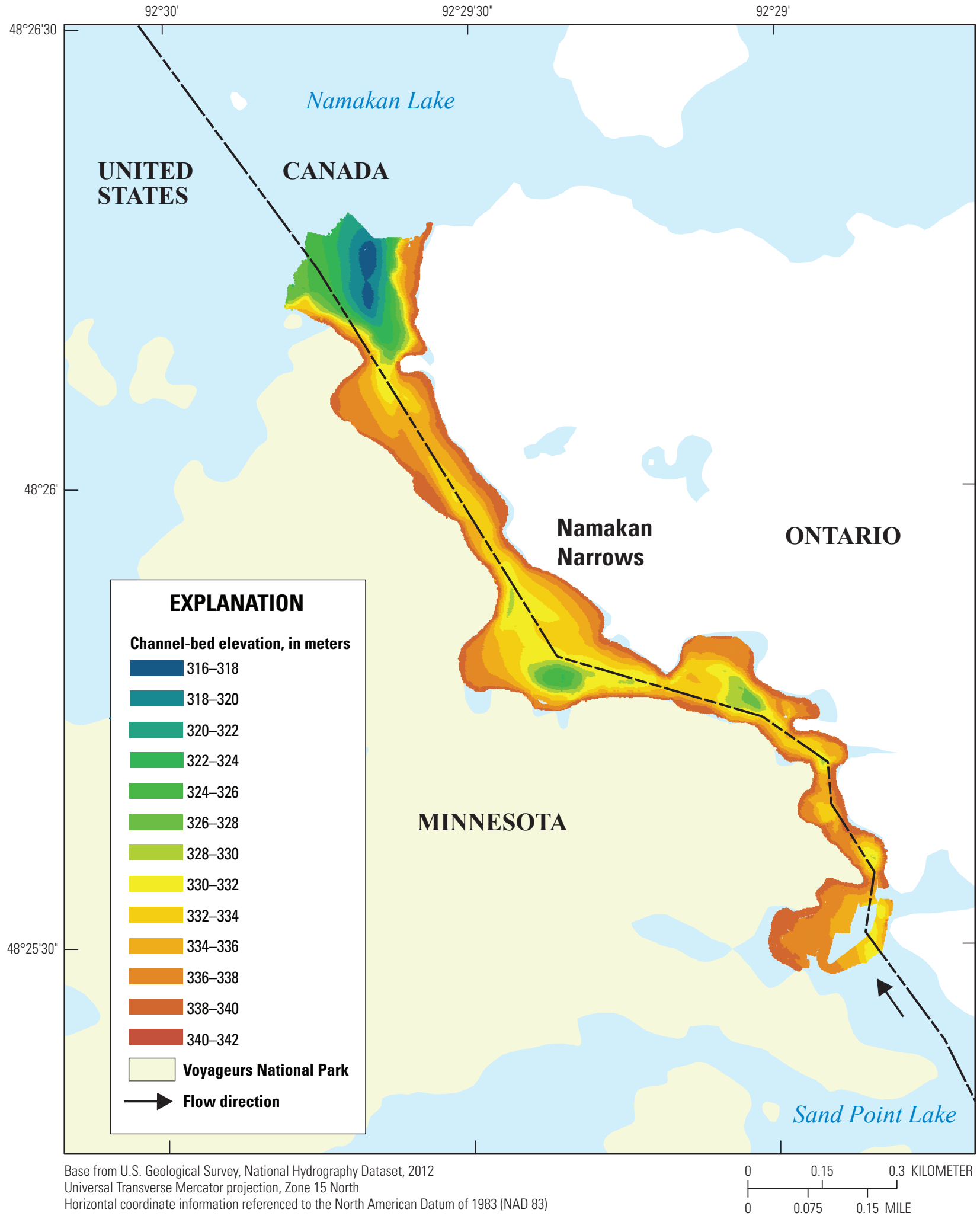

Figure 3. Bathymetry surveyed August 13, 2011, at Namakan Narrows, Sand Point Lake, Minnesota-Ontario. 


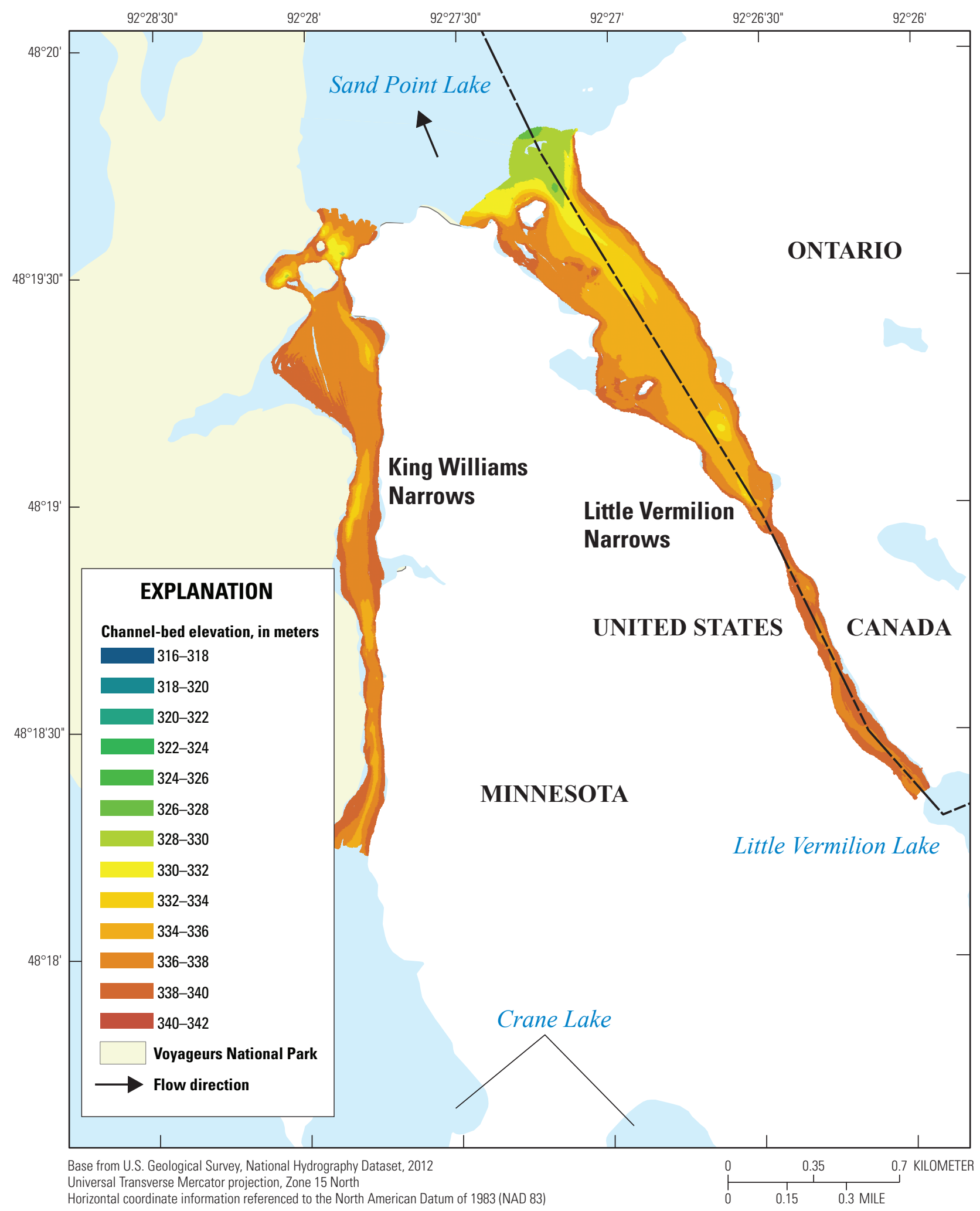

Figure 4. Bathymetry surveyed August 14, 2011, at Little Vermilion Narrows of Little Vermilion Lake, and August 15, 2011, at King Williams Narrows of Crane Lake, Minnesota-Ontario. 


\section{References Cited}

Applanix Corporation, 2006, POS MV TM V4 user guide, rev. D: Richmond Hill, Ontario, Canada, Applanix Corp., PUBS-MAN-000513, $369 \mathrm{p}$.

CARIS, 2011, Caris HIPS and SIPS 7.1 professional users guide: Fredericton, New Brunswick, Canada, CARIS, $474 \mathrm{p}$.

CARIS, 2012, CARIS HIPS and SIPS - Comprehensive hydrographic and bathymetric processing: Fredericton, New Brunswick, Canada, CARIS, accessed October 11, 2012, at http://www.caris.com/products/hips-sips/.

CARIS, 2013, CARIS easy view: Fredericton, New Brunswick, Canada, CARIS, accessed March 8, 2013, at http:// www.caris.com/products/easy-view/

Dartnell, P., Finlayson, D.P., Ritchie, A.C., Cochrane, G.R., and Erdey, M.D., 2012, Bathymetry and acoustic backscatter-Outer mainland shelf, eastern Santa Barbara Channel, California: U.S. Geological Survey Data Series 702, 6 p. (Also available at $h t t p: / / p u b s . u s g s . g o v / d s / 702 /$.)

Densmore, B.K., Strauch, K.R., and Dietsch, B.J., 2013, Hydrographic surveys of the Missouri and Yellowstone Rivers at selected bridges and through Bismarck, North Dakota, during the 2011 flood: U.S. Geological Survey Scientific Investigations Report 2013-5087, 59 p.

ESRI, 2012, ArcGIS-Mapping and analysis for understanding our world: Redlands, Calif., ESRI, accessed June 2012, at http://www.esri.com/software/arcgis.

HYPACK, Inc., 2007, HYPACK $®$ user's manual 1/07: Middletown, Conn., HYPACK, 991 p.

International Hydrographic Organization, 2008, IHO standards for hydrographic surveys (5th ed.): Monaco Cedex, Monaco, International Hydrographic Bureau, 36 p.

International Joint Commission, 2001, In the matter of emergency regulation of the level of Rainy Lake and of other boundary waters in the Rainy Lake Watershed: Washington, D.C., and Ottawa, Ontario, Canada, International Joint

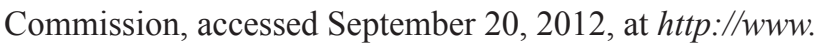
ijc.org/conseil board/rainy lake/docs/2001-01-18 IJC Order.pdf.

International Rainy Lake Board of Control, 1999, Final report—Review of the IJC order for Rainy and Namakan Lakes: St. Paul, Minn., and Burlington, Ontario, Canada, International Rainy Lake Board of Control, accessed September 19, 2012, at http://www.ijc.org/rel/boards/ rainylake/19991026_e.pdf.
Kallemeyn, L.W., Holmberg, K.L., Perry, J.A., and Odde, B.Y., 2003, Aquatic synthesis for Voyageurs National Park: U.S. Geological Survey Information and Technology Report 2003-0001, 95 p.

Kallemeyn, L., Darby, W.R., Eaton, E., Peterson, K., Smokorowski, K., and Van den Broeck, J., 2009, Plan of study for the evaluation of the IJC 2000 order for Rainy and Namakan Lakes and Rainy River: Washington, D.C., and Ottawa, Ontario, Canada, International Joint Commission, 2000 Rule Curve Assessment Workgroup, 55 p., accessed September 20, 2012, at http://www.ijc.org/rel/ boards/rainylake/POS_Workgroup_Final_Report_To_ IJC_30Jun09.pdf.

Kitchell, J.F., and Koshinsky, G.D., 1996, Review of proposed changes in water level regulation for Rainy and Namakan Lakes-Their consequent ecological effects on fisheries and related aquatic resources: Washington, D.C., and Ottawa, Ontario, Canada, International Joint Commission, accessed September 5, 2012, at http://www.ijc.org/rel/boards/ rainylake/19960731_e.pdfhttp://www.ijc.org/rel/boards/ rainylake/19960731_e.pdf.

National Geodetic Survey, 2011, GEOID09: Silver Spring, Md., National Geodetic Survey, accessed August 29, 2013, at http://www.ngs.noaa.gov/GEOID/GEOID09/.

National Geodetic Survey, 2012, OPUS - Online Positioning User Service: Silver Spring, Md., National Geodetic Survey, accessed May 11, 2012, at http://www.ngs.noaa.gov/OPUS/.

Rantz, S.E., and others, 1982, Measurement and computation of streamflow-Volume 1. Measurement of stage and discharge: U.S. Geological Survey Water-Supply Paper 2175, $284 \mathrm{p}$.

RESON, Inc., 2006, SeaBat ${ }^{\mathrm{TM}} 7125$ high-resolution multibeam echosounder system, version B066 080218/A4: Goleta, Calif., RESON, 2 p.

Revell, P., 2010, Extremes caused water levels to fluctuate outside rule curves: Fort Frances Times Online, accessed September 20, 2012, at http://www.fftimes.com/node/236165.

U.S. Geological Survey, 2012a, National Water Information System (NWISWeb): U.S. Geological Survey database, accessed May 11, 2012, at http://waterdata.usgs.gov/mn/ nwis/measurements. 
U.S. Geological Survey, 2012b, Water-resources data for the United States, Water 2012: U.S. Geological Survey Water-Data Report WDR-US-2012, site 482626092302001, 482147092291701, 482042092282501, and 481818092254201, accessed May 11, 2013, at

http://wdr.water.usgs.gov/wy2012/ $p d f s / 482626092302001.2012 . p d f$,

http://wdr.water.usgs.gov/wy2012/ $p d f$ /482147092291701.2012.pdf,

http://wdr.water.usgs.gov/wy2012/ $p d f / 482042092282501.2012 . p d f$, and

http://wdr.water.usgs.gov/wy2012/ $p d f_{s} / 481818092254201.2012 . p d f$. 


\section{Publishing support provided by:}

Rolla Publishing Service Center

For more information concerning this publication, contact: Director, USGS Nebraska Water Science Center 5231 South 19th Street Lincoln, Nebraska 68512 (402) 328-4100

Or visit the Nebraska Water Science Center Web site at: http://ne.water.usgs.gov/ 


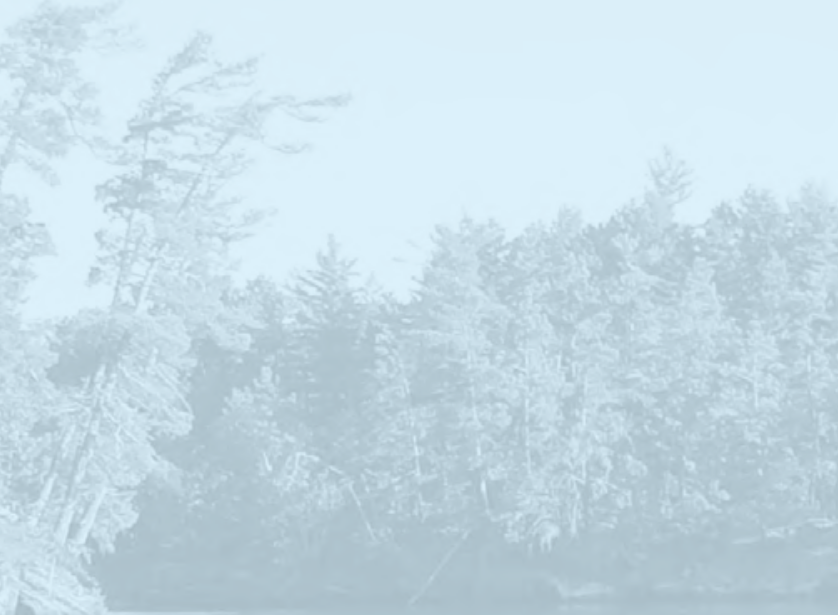

